ISSN 1991- 8690

website :http:// jsci.utq.edu.iq

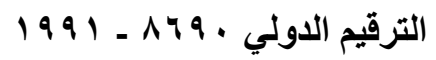

Email: utjsci@utq.edu.iq

\title{
Detection of Helicobacter pylori IgG in diabetic patients and non-diabetic
}

\author{
A.A.AL-Abdul
}

Department of philology college of science University of Basrah . Iraq

\section{Abstract}

Diabetes mellitus is one of the important causes of dyspepsia. The incidence of $H$. pylori is increased in diabetes mellitus. A total of ninety two (92) blood samples which include sixty two (62) samples for diabetic patient and thirty (30) samples non-diabetic as a control from November 2012 - March 2013 in private laborotary (Ibn- Alnafes) in Basra city. All samples were subjected to assessment of fasting blood sugar (FBS) level and detection of H. pylori antibodies (H. pylori $\mathrm{IgG})^{\#}$ by enzyme linked immunoabsorbent assay (ELIZA). The highest frequency of H.pylori was in diabetic patients 54/62(87\%), while non diabetic patients (as control), was 3/30(10). Statistically the differences were significant ( $\mathrm{P}<0.05)$ among diabetic and non-diabetic patients with $H$. pylori. For the diabetic patients, of the total 37/62(60\%) males, 32/37(86\%) showed positive test for H. pylori IgG, while 22/25(88\%) out of 25/62( $40 \%$ ) females, showed positive test of for $H$. pylori $\mathrm{IgG}$, but the difference was statistically non significant $(\mathrm{P}>0.05)$. For non diabetic group, of the total 18/30(60\%) males, 2/18(11\%) showed positive test for $\mathrm{H}$. pylori, and of the total 12/30( 40\%) females, 1/12(8\%) showed positive test for H.pylori IgG but the differences was statistically non significant $(\mathrm{P}>0.05)$ Age of patients and control range from 20-80 years, for diabetic and non-diabetic patients, the highest detection rates of $H$. pylori IgG was recorded in the age group (41-60) years, 33/37(89\%) and 2/10(20\%) respectively, while the lowest detection rate were recorded in the age group (20-40) years, 10/13(77\%) and 0/10(0\%) respectively. Statistically, the differences was significant $(\mathrm{P}<0.05)$ among these age groups.

الخلاصة:

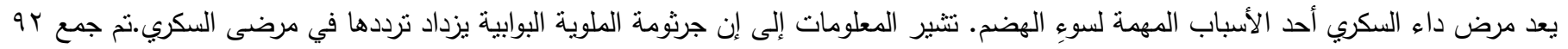

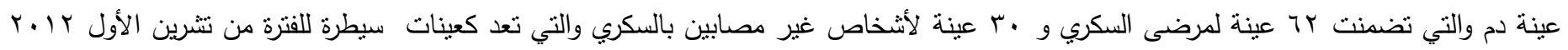

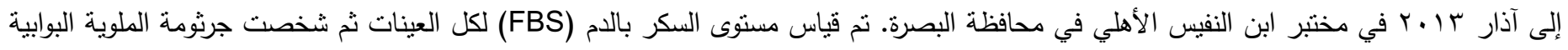

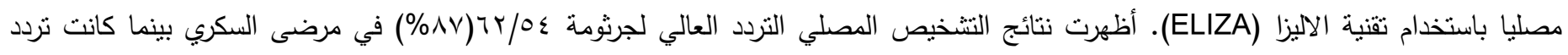

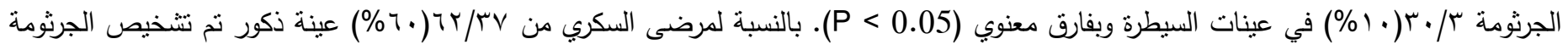

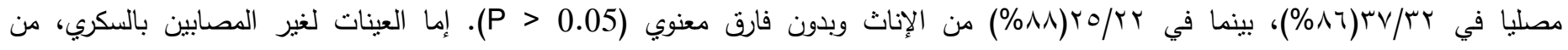

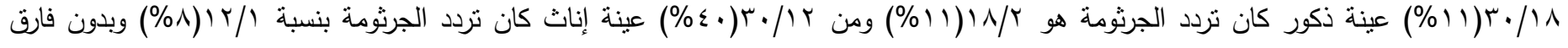

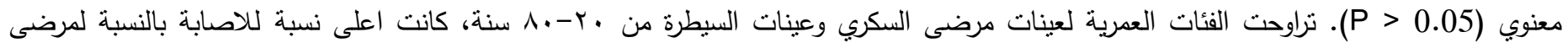

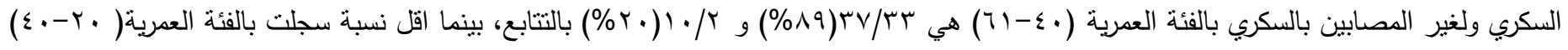

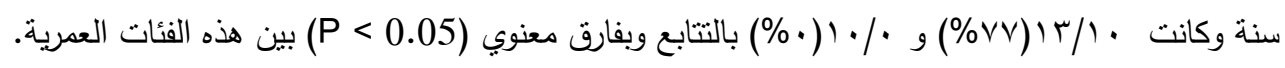

\section{Introduction}

Helicobacter pylori is a gram negative, spiral shaped, microaerophilic, pathogenic bacterium, infects the stomach of more than $50 \%$ of the human population worldwide and is a major cause of chronic gastritis, peptic ulcer, mucosa-associated lymphoid tissue (MALT) lymphoma, and gastric cancer (Suerbaum and Michetti, 2002). HP is also associated with coronary artery disease and its risk factor is diabetes
mellitus(Oldenburg et.al ,1996). Disordered gastrointestinal motor function is now recognized as a major cause of diabetes mellitus (Devrajani et.al, 2010). Diabetes mellitus, a chronic disease marked by high levels of sugar in the blood, is common and increasing around the world (Mokdad et.al, 2001). Our populationbased cohort study showed that patients with type 2 diabetes mellitus (T2DM) (non-insulin-dependent ,which infected the adult ), have a significantly higher risk of gastric cancer mortality (Tseng, 2012). The role 
of Helicobacter pylori infection in diabetic dyspepsia is mainly related to blood glucose concentration. Hyperglycemia may induce the infection by H. pylori or the silent infection may get reactivated and produce symptoms of dyspepsia in diabetic patients (Devrajani et.al, 2010).The mammalian stomach produces leptin and ghrelin, tow hormones involved in energy homeostasis(Schwartz et.al, 1996 and Shintani et.al, 2001). H. pylori is involved in the regulation of these two hormones (Francois et.al, 2011).

Aim: The objective of the present study was to determine the frequency of $\mathrm{H}$. pylori IgG by enzyme linked immunoabsorbent assay (ELIZA) in diabetic and non-diabetic patients.

\section{Material and methods}

\section{Sample collection}

A total of ninety two (92) blood samples which include sixty two (62) samples for diabetic patient and thirty (30) samples non-diabetic as a control from November 2012 - March 2013 in private laboratory (Ibn- Alnafes) in Basra city. All samples were subjected to assessment of fasting blood sugar (FBS) level (not for diagnostic purpose but to assess the blood sugar level whether it is controlled or un controlled for diabetic patients only).Detection of $\mathbf{H}$. pylori antibodies:- Detection of $\mathrm{H}$. pylori antibodies ( $\mathrm{H}$. pylori $\mathrm{IgG}) \#$ by enzyme linked immunoabsorbent assay (ELIZA). The Nova Tec Helicobacter pylori IgG - ELIZA is intended for the quantitative determination of IgG class antibodies against $\mathrm{H}$. pylori in human serum or plasma. The diagnostic specificity is $92 \%$ and sensitivity is $94.4 \%$. Micro titer strip wells are precoated with $\mathrm{H}$. pylori antigen to bind corresponding antibodies of the specimen. They were thirty seven (37) males and twenty five (25) females for diabetic patients and eighteen (18) males and twelve (12) females for non diabetic. Age of patients and control range from 20-80 years.Information obtained from the patient which include : name, age, sex, address, drug, period of infection with diabetes, treatment for diabetes and level of sugar in blood (FBS).

\# Helicobacter pylori IgG-ELIZA NOVA TEC IMMUNDIAGNOSTICA GMBH. Product Number : HELG 0220 (96 Determinations).

Statistical analysis : Data were analyzed by chi squire using SPSS program for window (version 15).

\section{Results}

A total of (92) patients were enrolled in the study. $62 / 92(67 \%)$ samples diabetic and 30/92(33\%) nondiabetic. Fifty four 54/62(87\%) from diabetic patient, were diagnosed with $\mathrm{H}$. pylori infection and 3/30(10\%) from non-diabetic, were diagnosed with $\mathrm{H}$. pylori infection and 5/62(8\%) samples show equivocal as shown in Table (1).

Table (1): Distribution of $H$. pylori IgG with diabetic and non-diabetic patients

\begin{tabular}{|c|c|c|c|c|}
\hline $\begin{array}{c}\text { Diabetic } \\
\text { With } \\
\text { HP }(+)\end{array}$ & $\begin{array}{c}\text { Diabetic } \\
\text { Without } \\
\text { HP }(-)\end{array}$ & $\begin{array}{c}\text { Equivocal } \\
\pm\end{array}$ & $\begin{array}{c}\text { non-Diabetic } \\
\text { With } \\
\text { HP }(+)\end{array}$ & $\begin{array}{c}\text { non-Diabetic } \\
\text { Without } \\
\text { HP }(-)\end{array}$ \\
\hline $54 / 62(87 \%)$ & $3 / 62(5 \%)$ & $5 / 62(8 \%)$ & $3 / 30(10 \%)$ & $27 / 30(90 \%)$ \\
\hline
\end{tabular}

Statistically the differences were significant $(\mathrm{P}<0.05)$ among diabetic and non-diabetic patients with $\mathrm{H}$. pylori.For the diabetic patients, of the total $37 / 62(60 \%)$ males, 32/37(86\%) showed positive test for $\mathrm{H}$. pylori IgG, while $22 / 25(88 \%$ ) out of $25 / 62$ ( $40 \%$ ) females, showed positive test of for $\mathrm{H}$. pylori $\mathrm{IgG}$, but the difference was statistically non significant $(\mathrm{P}>$ $0.05)$.For non diabetic group, of the total 18/30(60\%) males, $2 / 18(11 \%)$ showed positive test for $\mathrm{H}$. pylori, and of the total 12/30(40\%) females, 1/12(8\%) showed positive test for H.pylori IgG but the differences was statistically non significant $(\mathrm{P}>0.05)$ as shown in Table (2).

Table (2): Distribution of H. pylori IgG with diabetic and non-diabetic patients according to sex

\begin{tabular}{|c|c|c|c|}
\hline $\begin{array}{c}\text { Diabetic male } \\
\text { with H.pylori }\end{array}$ & $\begin{array}{c}\text { Diabetic female } \\
\text { with H.pylori }\end{array}$ & $\begin{array}{c}\text { non-Diabetic male } \\
\text { with H.pylori }\end{array}$ & $\begin{array}{c}\text { non-Diabetic female } \\
\text { with H.pylori }\end{array}$ \\
\hline $32 / 37(86 \%)$ & $22 / 25(88 \%)$ & $2 / 18(11 \%)$ & $1 / 12(8 \%)$ \\
\hline
\end{tabular}

Table (3) show also the distribution of cases in association with age groups. For diabetic and nondiabetic patients, the highest detection rates of $H$. pylori IgG was recorded in the age group (41-60) years $33 / 37(89 \%)$ and $2 / 10(20 \%)$ respectively, while the lowest detection rate were recorded in the age group (20-40) years $10 / 13(77 \%)$ and $0 / 10(0 \%)$ respectively. Statistically, the differences was significant $(\mathrm{P}<0.05)$ among these age groups. 
Table (3): Distribution of $H$. pylori IgG with diabetic and non-diabetic patients according to age group

\begin{tabular}{|c|c|c|c|c||}
\hline Age (years) & $\begin{array}{c}\text { No. } \\
\text { patient }\end{array}$ & $\begin{array}{c}\text { Diabetic with H. } \\
\text { pylori IgG }\end{array}$ & $\begin{array}{c}\text { No. } \\
\text { Control }\end{array}$ & $\begin{array}{c}\text { Non-Diabetic } \\
\text { with H. pylori } \\
\text { IgG }\end{array}$ \\
\hline $20-40$ & 13 & $10 /(77 \%)$ & 10 & $0 /(0 \%)$ \\
$41-60$ & 37 & $33 /(89 \%)$ & 10 & $2 /(20 \%)$ \\
$61-80$ & 12 & $11 /(92 \%)$ & 10 & $1 /(10 \%)$ \\
\hline
\end{tabular}

\section{Discussion}

Infection by $H$. pylori remains one of the most important scientific phenomena in the biomedical literature worldwide and represents the most prevalent chronic bacterial disease because it affects more than half of the world 's population, with a distribution related to the degree of economic development in each country (Medina et.al, 2010).The present study found that diabetic patients are more prone to acquire $H$. pylori infection, statistically significant $(\mathrm{P}<0.05)$. Studies regarding $H$. pylori infection rate in patients with type 2 diabetic mellitus are still scarce. A hospitalbased case-control study from Pakistan enrolling 74 patients with T2DM and 74 non-diabetic controls suggested that diabetic patients have a higher infection rate (73\%) (Devrajani et.al, 2010). Study from the United Arab Emirates (Bener et.al, 2008), showed a higher infection rate as observed in 210 patients with T2DM. Similar results were also detected in the study conducted in Japan ( Kimiaki et.al, 1999).However, the higher prevalence of $\mathrm{H}$. pylori infection was also reported in diabetic mellitus than in non-diabetic in a study by Marrollo et.al, (2001), Chen and Blaser , (2012), they concluded that the finding indicate a role of $\mathrm{H}$. pylori in impaired glucose tolerance in adults that may be potentiated by higher body mass index (BMI) level. Tseng, (2012), found that type 2 diabetes and insulin use in the diabetic patients are significantly associated with a higher incidence of $\mathrm{H}$. pylori eradication. In contrast, other studies showed that $\mathrm{H}$. pylori infection is not associated with DM, as there is no difference in the prevalence of $\mathrm{H}$. pylori infection between diabetic and non-diabetics (Anaslasios et.al, 2002), and a Turkish study in 141 patients with T2DM and 142 controls showed no significant difference between the two groups (Demir et.al., 2008), likely due to inconsistencies in the methods used to define $\mathrm{H}$. pylori positivity and diabetes status, the limited sample size, and adjustments for potential confounders (Xia e.t al, 2001).H. pylori plays a role in the regulation of leptin and ghrelin (Francois et.al, 2011; Gunji et.al, 2008; Isomoto et.al, 2005; Nwokolo et.al, 2003 and Roper et.al, 2008) which are central to energy homeostasis and metabolism (Sun et.al, 2006 and Williams and Mobarhan, 2003), H. pylori induces gastric inflammation, the $\mathrm{H}$. pylori-positive stomach and the $\mathrm{H}$. pylori-negative stomach are markedly different in terms of T-cell and B-cell populations (Peek et.al, 1995; Robinson et.al, 2008 and Harris et.al, 2008) these have a local effect, but there is increasing evidence for global effects (Arnold et.al, 2011). Ghrelin is a novel 28-amino acid peptide hormone that is secreted by endocrine cells in the stomach (Kojima et.al, 1999), low plasma ghrelin concentration were significantly lower in $\mathrm{H}$. pylori -positive patients than H. pylori -negative controls (ShiotaNi et.al, 2005).In present study, H. pylori infection in both groups diabetic and non-diabetic, were more in the age group (41-60) years, while the lowest detection rate were recorded in the age group (20-40) years. Statistically, the differences was significant $(\mathrm{P}<0.05)$ among these age groups. Study of Devrajani et.al, (2010), the majority of the patients with $\mathrm{H}$. pylori infection in both groups - diabetic and non diabetic, were more than 50 years of age where as in another study the mean age was 60 years(Ugwu et.al, 2008). However, a study by Sargyn et.al, (2003) showed that the mean age of diabetic patients with $\mathrm{H}$. pylori infection is 56 years. The present study shows that $\mathrm{H}$. pylori infections were more common among males. De Martel et.al, (2006), confirmed the male predominance of H.pylori infection. On the other hand, in another study the $\mathrm{H}$. pylori infected females were predominant as compared to males (Kanbay et.al, 2005).Antibody testing relies upon the detection of IgG antibodies specific to $\mathrm{H}$. pylori in serum, whole blood, or urine. IgG antibodies to H. pylori typically become present approximately 21 days after infection and can remain present long after eradication ( Ho and Marshall, 2000). Antibodies to H. pylori can be quantitatively assessed using enzyme linked immunoabsorbent assay (ELIZA) and latex agglutination technique. ELIZA, is the technique of choice to detect antibodies against $\mathrm{H}$. pylori ( $\mathrm{IgG}$ ) in serum samples, these circulating antibodies can be detected in the blood (Gisbert, 2000), saliva and urine (Gisbert, 2000 and De Boer et.al, 2000) with an excellent sensitivity, approaching 95\%, but a low specificity.In our study used ELIZA technique to detect antibodies against $\mathrm{H}$. pylori IgG in serum samples. The advantages of the antibody tests are widespread 
availability, rapid results, and have specificity and sensitivity, 92 and 94.4 respectively.

\section{Conclusions}

Our results demonstrated an increased risk of $\mathrm{H}$. pylori infection among diabetic patients and the frequency of H.pylori was higher in diabetic patients than in non-diabetic.

\section{Recommendation}

Study the relationship between H.pylori infection and diabetic patients type-1 (T1DM, which infected children and depends on insulin).

\section{References}

Anastasios, R.; Goritsas, C.; Papamihail, C.; Trigidou, R.; Garzonis, P. and Ferti, A. (2002). Helicobacter pylori infection in diabetic patients: prevalence and endoscopic findings. Eur J Intern Med. ;13:376.

Arnold, I.C.; Dehzad, N.; Reuter, S.; et al. (2011). Helicobacter pylori infection prevents allergic asthma in mouse models through the induction of regulatory T cells. J Clin Invest;121:3088-93

Bener, A.; Micallef, R.; Afifi, M.; Derbala, M.; AlMulla, H.M.; Serin, E. and Yilmaz, U. (2008). Helicobacter pylori prevalence in diabetes mellitus patients with dyspeptic symptoms and its relationship to glycemic control and late complications. Dig. Dis. Sci., 53: 2646-2649.

Chen , Y.U. and Blaser, M. J. (2012).Association Between Gastric Helicobacter pylori colonization and Glycated Hemoglobin Levels. J. Infectious Diseases Advance Access .

De Boer, W.A.; De Laat, L. and Megraud, F.(2000). Diagnosis of Helicobacter pylori infection. Current Opinion in Gastroenterol .; 16 (Supl. 1): S5-S10.

de Martel, C. and Parsonnet, J.(2006). Helicobacter pylori infection and gender: A meta-analysis of population-based prevalence surveys. Dig Dis Sci. ;51:2292-301.

Demir, M.; Gokturk, H.S.; Ozturk, N.A.; Kulaksizoglu, M.; Serin, E. and Yilmaz, U. (2008). Helicobacter pylori prevalence in diabetes mellitus patients with dyspeptic symptoms and its relationship to glycemic control and late complications. Dig Dis Sci, 53:2646-2649.

Devrajani, B.R.; Ali Shah, S.Z; Soomro, A.A. and Devrajani, T. (2010). Type 2 diabetes mellitus: A risk factor for Helicobacter pylori infection: A hospital based case-control study.

Francois, F.; Roper, J; Joseph, N.; et.al. (2011). The effect of H.pylori eradication on meal-associated changes in plasma ghrelin and leptin. BMC. Gastroenterol. ; 11:37.

Gisbert, J.P. (2000). Revisión crítica de los métodos diagnósticos de infection por Helicobacter pylori. Gastroenterol Hepatol; 23: 135-43.

Gunji , T. ; Matsuhashi, N.; Sato, H.; et al. (2008). Helicobacter pylori infection is significantly associated with metabolic syndrome in the Japanese population. Am J Gastroenterol;103:3005-10.

Harris, P.R.; Wright, S.W.; Serrano, C.; et al. (2008). Helicobacter pylori gastritis in children is associated with a regulatory $\mathrm{T}$-cell response. Gastroenterol. ;134:491-9

Ho, B. and Marshall, B.J. (2000). Accurate diagnosis of Helicobacter pylori. Serological testing. Gastroenterol. Clin. N Am.; 29: 853-62.

Isomoto, H.; Ueno, H.; Nishi ,Y.; Wen ,C.Y.; Nakazato , M. and Kohno, S.(2005). Impact of Helicobacter pylori infection on ghrelin and various neuroendocrine hormones in plasma. World J Gastroenterol ;11:1644-8.

Kanbay, M.; Gür, G.; Arslan, H.; Yilmaz, U. and Boyacioglu, S. (2005). The Relationship of ABO Blood Group, Age, Gender, Smoking, and Helicobacter pylori Infection. Dig Dis Sci. ;50:1214-7.

Kimiaki, N.; Takahiro, K.; Hajime, G.; Kazuaki, K.; Tadatoshi, K.; Shigetoshi ,M.; et al. (1999). Effects of Helicobacter pylori on gastroduodenal disorders in diabetes mellitus. J Nara. Med. Assoc. ;386:24-8.

Kojima, M.; Hosoda, H.; Date, Y.; et.al. (1999).Ghrelinis a growth-hormone-releasing 
acylated peptide from stomach. Nature, 402: 656660.

Marrollo, M.; Latella, G.; Melideo, D.; Storelli, E.; Iannarelli, R.; Stornelli , P.; et al.(2001). Increased prevalence of Helicobacter pylori in patients with diabetes mellitus. Dig. Liver Dis. ;33:21-9.

Medina, M.L; Medina, M,G; Martin, G.T. ; Picon, S.O.; Bancalari, A. and Merino, L.A. (2010). Molecular detection of Helicobacter pylori in oral samples from patients suffering digestive pathologies. Med. Oral. Patol. Oral. Bucal.; 15: e38-e42.

Mokdad, A.H.; Bowman, B.A.; Ford, E.S.; Vinicor, F.; Marks, J.S. and Koplan, J.P. (2001). The continuing epidemics of obesity and diabetes in the United States. JAMA; 286: 1195-200.

Nwokolo, C.U.; Freshwater ,D.A.; O'Hare, P. and Randeva , H.S. (2003). Plasma ghrelin following cure of Helicobacter pylori. Gut 2003;52:637-40

Oldenburg, B.; Diepersloot, R.J. and Hoekstra, J.B. (1996). High seroprevalence of Helicobacter pylori in diabetes mellitus patients. Dig Dis Sci ;41: 458-461.

Peek, R.M.; Miller, G.G.; Tham , K.T.; et al. (1995). Heightened inflammatory response and cytokine expression in vivo to cagA+ Helicobacter pylori strains. Lab Invest;73:760-70

Robinson, K.; Kenefeck, R.; Pidgeon, E.L.; et al. (2008). Helicobacter pylori-induced peptic ulcer disease is associated with inadequate regulatory T cell responses. Gut ;57:1375-85

Roper, J.; Francois, F.; Shue, P.L.; et al. (2008). Leptin and ghrelin in relation to Helicobacter pylori status in adult males. J Clin Endocrinol Metab ;93:2350-7.

Sargýn, M.; Uygur-Bayramicli, O.; Sargýn, H.; Orbay, E.; Yavuzer, D. and Yayla, A.(2003). Type 2 diabetes mellitus affects eradication rate of Helicobacterpylori. WorldJGastroenterol. ;9:1 126-8.

Schwartz, M.W.; Seeley, R.J.; Campfield, L.A.; Burn, P. and Baskin, D.G. (1996). Identification of targets of leptin action in rat hypothalamus. J. Clin. Invest.; 98:1101-6.

Shintani, M.; Ogawa, Y.; Ebihara, K.; et.al. (2001). Ghrelin, an endogenous growth hormone secretagogue, is a novel orexigenic peptide that antagonizes leptin action through the activation of hypothalamic neuropeptide $\mathrm{Y} / \mathrm{Y} 1$ receptor pathway. Diabetes; 50:227-32.

Shiotani, A.; Miyanishi, T.; Uedo, N.; et.al. (2005). Helicobacter pylori infection is associated with reduced circulating ghrelin levels independent of body mass index. Helicobacter; 10: 373-378.

Suerbaum, S. and Michetti, P. (2002). Helicobacter pylori infection. N Engl J Med ;3: 1175-1186.

Sun, Y.; Asnicar, M.; Saha , P.K.; Chan, L. and Smith, R.G. (2006). Ablation of ghrelin improves the diabetic but not obese phenotype of ob/ob mice. Cell Metab ;3:379-86

Teseng, C.H. (2011). Diabetes conveys a higher risk of gastric cancer mortality despite on agestandardized decreasing trend in the general population in Taiwan. Gut, 60: 774-779.

Teseng, C.H. (2012). Diabetes, Insulin Use and Helicobacter pylori Eradication. BMC. Gastroenterol.; 12(46).

Ugwu, N.C.; Ugwuja, E.I.; Ejikeme, B.N. and Obeka,N.C.(2008) Helicobacterpylori Seropositi vity in Nigerians with Type 2 Diabetes Mellitus. Internet J Trop Med. ;4:32-6.

Williams, J. and Mobarhan, S. A . (2003). critical interaction: leptin and ghrelin. Nutr Rev;61:391-3

Xia, H.H.;Talley, N.J.; Kam, E.P.; Young, LJ.; Ham mer, J. and Horowitz, M.(2001). Helicobacter pyloriinfection is not associated with diabetes mellitus, nor with upper gastrointestinal symptoms in diabetes mellitus. Am J Gastroenterol ;96:1039-46. 